geheel afwijkende conclusies komen op grond van een onderzoek dat van dezelfde gegevens gebruik maakte.

Het spreekt welhaast vanzelf dat tenslotte de twee collega's wel tot een gemeenschappelijk standpunt zullen komen in zo'n geval. Dit neemt niet weg dat de public accountant onder een stelsel van geleide economie tot een dusdanige objectivering van zijn gezichtspunten zal moeten komen dat hij, gesteld voor een bepaald vraagstuk, tot dezelfde conclusies zal moeten komen als zijn collega-ambtenaar. Men zou in feite tot de slotsom moeten komen dat onder geleide economie geen principiëel onderscheid tussen overheidsaccountant en public-accountant meer bestaat en dat één van de twee categorieën gevoegelijk zou kunnen verdwijnen.

Een verbreding en verdieping van de wetenschappelijke basis, waarop zijn techniek steunt; een verruiming en verzwaring van de verantwoordelijkheid, die hij door zijn verklaringen en rapporten op zich neemt; een steeds verder gaande objectivering ten aanzien van de hem voorgelegde vraagstukken; dit zijn aspecten, die de geleide economie de huidige accountant biedt.

\title{
AL OF NIET RENTEVERGOEDING DOOR DE FISCUS BIJ TOE- WIJZING VAN RECLAME-, BEROEPS- OF CASSATIEZAKEN?
}

door G. A. van Hout

In de huidige omstandigheden, waarin de belastingtarieven een enorme hoogte bereiken en de behandeling c.q. afdoening der zaken het normale tijdsbestek verre overschrijdt, is dunkt me de vraag, of het billijk te achten is, dat de Staat rente vergoedt over de restituties door de fiscus te verlenen, alleszins gewettigd. Het behoort wellicht nog heden tot de zeldzaamheden, dat de afdoening van een beroepszaak, om van de behandeling van reclamezaken i.v.m. de fiscale zuivering maar niet te spreken, om en om de twee jaar in beslag neemt. Indien de procedure is ingezet om belangrijke bedragen is hier terecht voor de appellant van renteverlies sprake. Met des te meer reden kan men zich deze vraag stellen, indien de trage behandeling enkel en alleen aan de fiscus is te wijten.

Ik meen dat er alle aanleiding bestaat om deze vraag eens van uit een tweetal gezichtspunten nader onder het oog te zien en wel ten eerste uit billijkheidsoverwegingen en ten tweede ook juridisch.

Uit billijkheidsoverwegingen kan het volgende geconstateerd worden:

1. De Staat heeft in een dergelijk geval gedurende twee jaar de beschikking gehad over een kapitaal, dat de fiscus blijkens de uitspraak dient te restitueren.

2. De Staat heeft daarmede gedurende die tijd zijn organen kosteloos gefinancierd.

3. Wanneer de staatsfinanciën in goeden doen verkeerden, dan ware het zelfs niet onmogelijk, dat dit kapitaal bij belegging of investering de Staat zelfs in die tijd een nog groter geldelijk voordeel zou hebben opgeleverd.

4. Wanneer de Staat gelden van derden opneemt, wordt daarover rente vergoed.

5. Wanneer de fiscus uitstel van betaling verleent voor normale belastingaanslagen, wordt daarbij rentevergoeding bedongen.

m a b blz. 172 
Juridisch valt hieromtrent m.i. in verband met het voorgaande het volgende op te merken:

a) Vgl. P.J.A. Adriani in ,De grondbeginselen der wetten op de Inkomsten-, Vermogens- en Dividend en Tantièmebelasting" ontstaat de belastingschuld uit de wet. Dit wordt tegenwoordig vrij algemeen aangenomen; ook de $\mathrm{H}$. R. deelt deze opvatting. $E_{\mathrm{r}}$ zijn echter voor verschillende belastingen zekere ambtelijke verrichtingen nodig, om de schuld op een zeker bedrag vast te stellen en invorderbaar te maken. Dit geschiedt door de aanslagregeling. De belastingplichtige die op het kohier is gebracht is de schuldenaar in de uit kracht der wet ontstane belastingschuld. Tot zover Adriani.

In wezen verleent de fiscus dus automatisch uitstel van betaling tot het opleggen van de aanslag en vervolgens tot de op het aanslagbillet vermelde vervaldagen. Daarnaast is de Ontvanger in bonafide gevallen in het algemeen wel genegen om voor het belastingbedrag, waarover verschil van mening met de inspecteur bestaat, uitstel van betaling te verlenen tot nä de vaststelling van de definitieve aanslag of tot nă de uitspraak op het bezwaarschrift. De kwestie van betaling doet zich dus voor bij betwisting van de uitspraak van de Inspecteur resp. het opleggen van de definitieve aanslag. Dan immers dient in elk geval betaald te worden en vervalt een eventueel verleend betalingsuitstel.

b) De terugbetaling van de Staat komt dus eerst vast te staan ná de uitspraak op het bezwaar- of beroepschrift, zodat van renteverlies voor belanghebbende eerst sprake is in de periode tusschen betaling en de betreffende uitspraak, die restitutie voorschrijft.

c) Indien nu tussen de latere vaststelling van de negatieve schuldplicht en de datum van betaling in belangrijke zaken een groot tijdsbestek is gelegen, zooals hiervoor b.v. gesignaleerd, dan is het duidelijk, dat er van renteverlies voor de bel. pl. sprake kan zijn.

Gezien de hoge rente, die bij uitstel geeist wordt, $f 0.30$ per maand per $f$ 100. - is het dunkt me niet meer dan billijk, dat de Staat tot rentevergoeding overgaat, ook al kan bel. pl. juridisch daarop geen aanspraken doen gelden.

\section{Naschrift.}

Er bestaat zeker aanleiding om deze vraag onder de tegenwoordige omstandigheden onder de ogen te zien.

Daarbij wil ik het volgende opmerken:

1. Volgens een oud arrest H. R. van 1877 zijn ingeval van terugvordering van onverschuldigde rechten, moratoire interesten verschuldigd. Dan wordt art. 1286 B.W. toepasselijk geacht, dat voorschrijft dat interest verschuldigd is van de dag dat de geldsom ,in rechten" gevorderd is. In successie en registratiezaken wordt dan ook moratoire interest door de Staat betaald, indien de rechter de Staat veroordeelt het onverschuldigd betaalde terug te geven. Merkwaardig is het, dat art. 96 Succ. wet oorspronkelijk bepaalde, dat geen interesten hoegenaamd door of van de belastingschuldigen worden gevorderd en dat die bepaling in 1926 is ingetrokken, omdat die oniillijk werd geacht. Daardoor werd de rentevergoeding door de Staat weer noodzakelijk na veroordeling door de rechter. Zover ik weet wordt art. 1286 B.W. niet toepasselijk geacht, indien een aanslag door de Raad van Beroep wordt vernietigd of verminderd. 
2. Indertijd is door de Minister van Financiën te kennen gegeven, dat rentevergoeding "vermeerdering van omslag in de comptabiliteit" zou meebrengen (toelichting op het vroegere art. 96 Succ. wet). Maar die bezwaren zijn zeker te ondervangen door voorschriften, waardoor de renteberekening zou worden vereenvoudigd.

3. Ik zie geen reden waarom de gedachte, ten grondslag liggend aan art. $1286 \mathrm{~B}$. W. ook hier niet zou gelden. Uit een oogpunt van recht en billijkheid ondersteun ik dus hetgeen de inzender aanvoert. Er moet een beperking zijn tot enigszins grote bedragen, maar dan zou ik de rentevergoeding ook niet willen beperken tot de gevallen waarin de rechter of de Raad van Beroep beslist, doch in alle gevallen waarin de fiscus erkent te veel belasting te hebben geheven.

4 . In het buitenland wordt deze zaak op verschillende wijze behandeld; in Duitschland b.v. wordt geen rente vergoed, maar in België wel. Art. 74 al. 2 der Samengesch. wetten op de inkomstenbelasting luidt: ..bij terugbetaling van ten onrechte geinde belastingen zijn de achterstallige interesten verschuldigd, tegen hetzelfde bedrag als voor de interesten wegens vertraagde betaling, vanaf den dag na dien der betalingen tot den dag na dien der ontvangst van het bericht waardoor de belanghebbende wordt gewaarschuwd dat het bedrag der ontheffing te zijner beschikking is".

P. J. A. ADRIANI.

\section{UIT HET BUITENLAND}

\section{Hogeschoolopleiding als eis voor C.P.A.'s in de Staat New York, gezien van het standpunt van de practijk}

Onder deze titel geeft Raymond G. Ankers C.P.A. in het Novembernummer van The New York Certified Public Accountant de volgende uiteenzetting.

The New York State C.P.A.-wet bepaalt, dat candidaten voor het accountantsexamen graduates moeten zijn van Colleges of van Accountancy scholen, die onder toezicht staan van het State Education Department. Om te voldoen aan de vereisten moet de school een 4-jarige cursus organiseren van culturele en zakelijke onderwerpen, waarvan 24 uren boekhouden en accountancy, 8 uren elk handelsrecht en financiewezen en 6 uren economie.

Voor het in werking treden dezer wet gaven acountantskantoren ook voorkeur aan "College graduates" voor de aanvulling van hun staf, doch er was weinig uniformiteit in de schoolopleiding. Sommige afgestudeerden hadden hun graad in accountancy behaald, doch andere bezaten te geringe technische training - zo zij die al hadden - om hen bekwaam te doen $z$ ijn voor het accountantsberoep. De accountants hadden geen keus; zij wisten, dat zij goed opgeleide mensen nodig hadden, doch vonden slechts een beperkt aanbod van gegradueerden in accountancy, die van plan waren om accountancy als beroep te gaan uitoefenen. Ingevolge de instelling der wet kunnen de accountants de lijst der scholen raadplegen om te beoordelen of de candidaten aan bepaalde minimum eisen voldoen.

Er zijin twee voorname redenen, waarom $z$ ij de vroegere methode niet wensen voort te zetten. In de eerste plaats hebben mensen zonder de nodige technische kennis te veel tijd nodig om zich te ontwikkelen. .,College graduates" met weinig of geen opleiding in accountancy hebben ongeveer 4 jaar nodig om de hoogte te bereiken van een ,,semi senior accountant", terwijl de afgestudeerden hiervoor de halve tijd nodig heb-

ma b blz. 174 